\title{
A FRAMEWORK FOR AVOIDING HUMAN RIGHTS SCRUTINY: NORTH KOREA AND THE RESPONSIBILITY TO PROTECT (R2P)
}

\author{
Jed Lea-Henry ${ }^{a}$
}

\begin{abstract}
The doctrine of the Responsibility to Protect $(R 2 P)$ was designed to bridge the divide between best humanitarian practice and the sovereign protection of states. Its applicability to the grave human rights abuses in North Korea, as expounded in the United Nations Commission of Inquiry report, were immediately obvious. By the letter of the doctrine, North Korea should have been subject to an R2P-led intervention in order to halt systemic human rights abuses that the regime in Pyongyang proved unwilling to address themselves. Yet through a series of factors - designed and un-designed - the North Korean state has managed to construct an avoidance framework for interventions of this kind - a replicable standard by which the international community will go to extraordinary lengths to avoid living up to their human rights obligations in the face of continuing violations by obstinate states.
\end{abstract}

Keywords: North Korea, human rights, Responsibility to Protect, humanitarian intervention

\section{INTRODUCTION}

First conceived in 2001, by a made-for-purpose panel and the International Commission on Intervention and State Sovereignty (ICISS), the doctrine of the Responsibility to Protect (R2P) had a simple purpose behind it: to properly converge best humanitarian practices with the sovereign protection of states. To do this, R2P changed and redefined sovereignty to a 'functional' principle. Sovereignty would become contingent upon the upkeep of basic human rights. Any state failing to achieve this baseline standard, whether by incapacity or deliberate action, surrenders their sovereignty to the international community who are obligated to intervene and remedy the situation, and this 'obligation' must take the form of full, or partial, humanitarian intervention (military engagement) if the violating state in question breaches the baseline human rights of its population with either ethnic cleansing, genocide, grave or systemic war crimes, and crimes against humanity. As much as anything, R2P was a response to the human rights catastrophes that occurred in the 1990s and early 2000s, and the moral and practical failures of the international community to address these situations effectively.

The applicability of R2P to grave human rights abuses in North Korea was obvious from the doctrine's implementation, and more so after the United Nations Commission of Inquiry report (A/HRC/25/63) on February 7, 2014. By the letter of R2P, North Korea should have been subject to an R2P-led intervention in order to halt systemic human rights abuses that the regime in Pyongyang proved unwilling to address

a Jed Lea-Henry (jedlea_sh@vignan.ac.in) is an Assistant Professor of Humanities and Social Sciences, Vignan University, Guntur, India. 
themselves. Yet through a series of factors - designed and un-designed - the North Korean state has managed to construct an avoidance framework for interventions of this kind, a replicable standard by which the international community will go to extraordinary lengths to avoid living up to their human rights obligations in the face of continuing violations by obstinate states.

\section{NORTH KOREA'S HUMAN RIGHTS LANDSCAPE}

Occupied by the Japanese empire until the end of the Second World War, the Korean Peninsula upon its liberation was divided at the $38^{\text {th }}$ parallel, with the Soviet Union occupying the north, while the United States occupying the southern half. An original plan for the division to be temporary was soon abandoned after the Soviet Union refused to allow the United Nations access to their controlled territory for a planned peninsulawide election. This moment became the catalyst for long building security concerns about the peninsula and its relationship to the fallen Japanese empire, to force the division to be permanent. As the Cold War hostilities built up, the Korean nation increasingly lost sight of any real hopes for reunification. The Korean War closed this door entirely, and set in train the emergence of a North Korean state that was beyond the influence of its Soviet and Chinese sponsors, and increasingly committed to a rare form of race-based nationalism. In 1953, the Korean Armistice Agreement was signed, formally ending the fighting by respecting a Demilitarized Zone (DMZ) as a buffer zone between the opposing forces, but significantly not ending the war itself.

North Korean leader Kim Il-sung, after instigating the conflict, and failing to run the length of the peninsula within a month as he promised, was soon pushed back to his northern border, where war-fighting control was taken from him by Chinese ground forces and Soviet air power. Marginalised until the armistice was signed, Kim quickly set about removing any and all groups/individuals opposed to his rule that might challenge him in the future. North Korea rolled through shallow flirtations with Communism, and the manufacturing of a false veneer of Juche thought. The proclamation of Songun - or 'Military First Policy' - was the only large scale, openly announced, policy of this kind that touched on any truth. North Korea was a police state with a scale and oppression that surpassed anything that was seen in the old Soviet Union. The North Korean state claims to defend its citizenry from a predatory outside world, and for this, a cult of personality and devotion to the Kim dynasty, and absolute commitment to the state's guidance are demanded. From this slave-state ideology, comes a punishment regime and ruling methodology that looms over all social and cultural life, and produces an unprecedented and unconscionable human rights deficit.

The question of North Korea's human rights always hits the same challenge access to information. North Korea is a notoriously closed society, with foreigners rarely allowed access. And when they are, it is generally for tour guided 'dark' vacations, or similarly tour guided humanitarian work. But, in recent years the northern border with China has become increasingly porous, with North Korean and Chinese firms conducting small scale trade. Adding to this, is the steady build of North Korean defectors who have fled the country and managed to make it through Chinese territory and on to third countries willing to grant them asylum. The information black hole over North Korea's human rights landscape is opening up piece-by-piece, despite the country's refusal to 
acknowledge even the most minor of offenses, and refusal to cooperate in any manner with international investigations.

And so, it began with the most thorough analysis of North Korean human rights to date. On March 21, 2013, the United Nations Human Rights Council passed a resolution (A/HRC/RES/22/13) that set in place a 'Commission of Inquiry' in order to investigate the mounting evidence that North Korean violations "may amount to crimes against humanity." On February 7, 2014, and after a series of public hearings, the Commission of Inquiry published its final report (A/HRC/25/63), under which it charged North Korea with "extermination, murder, enslavement, torture, imprisonment, rape, forced abortions and other sexual violence, persecution on political, religious, racial and gender grounds, the forcible transfer of populations, the enforced disappearance of persons and the inhumane act of knowingly causing prolonged starvation." Noted in the report, was that these were not just historical charges, but were 'ongoing' in nature. And importantly, the responsibility for these human rights violations was attributed to the highest levels of government, focusing on the Kim dynasty and its immediate inner circle (Cohen 2013).

This represented an important step forward. Rather than merely 'expressing concern' about North Korea's human rights situation, as the various branches of the United Nations and different Non-governmental Organisations (NGO's) have often done, this was a clear and open, undiluted accusation, based on all the available evidence (North Korea as expected denied access to their country for the investigators). What was explained in the report was 70 years of continuous, unchecked, systematic human rights abuses without parallel elsewhere in the world. The difficulty in collating such human rights violations could not be understated, and its impact would have been significant regardless of the outcome if, as nothing more, than a message to the regime in Pyongyang that an accurate database of North Korea's human rights violations is still possible to be created in the face of their intransigence, and that these crimes might very well be used one day for future prosecutions, from prison guards upwards. The report was 372 pages long, and was based out of a permanent human rights office in Seoul, and documented nine specific areas of crimes that constitute widespread, systematic and grave violations of human rights, amounting to the charge of crimes against humanity. Following this, Hogan Lovells Law Firm in London ran an independent analysis of the report, and beyond agreeing with its findings, recommended expanding the charge of crimes against humanity to include the narrow and difficult-to-apply legal category of genocide, based on North Korea's persecution of 'hostile classes' and Christian populations, along with the practice of applying forced abortions on mixed race foetuses.

The documented abuse falls into the "not exhaustive" groupings of: 1. Violations of the right to food. 2. The full range of violations associated with prison camps. 3 . Torture and inhuman treatment. 4. Arbitrary arrest and detention. 5. Discrimination, in particular in the systemic denial and violation of basic human rights and fundamental freedoms. 6. Violations of freedom of expression. 7. Violations of the right to life. 8. Violations of the freedom of movement. 9. Enforced disappearances, including in the form of abductions of nationals of other States, with the caveat that "where appropriate, the commission also investigated violations intrinsically linked to one of the nine areas". The United Nations Commission put weight behind the numerous claims of academics, governments and NGOs over the years as to the full available scope of North Korea's 
human rights violations, and continues to stand as an incredibly thorough and damning assessment of the Kim regime (United Nations Human Rights Council 2014).

\section{HUMANITARIAN INTERVENTION}

North Korea's response to the United Nations human rights findings was to dismiss the whole exercise as "the imperialists' human rights racket" (Reuters 2017). With that, the call by the United Nations for the Kim regime to improve the situation in regard to their findings, was dismissed as well. In the days after the report was announced, a spattering of small nations that still held diplomatic relations with North Korea severed their ties, but the force behind the document was implicit in the call for a United Nations Security Council (UNSC) referral. Understandably, the Kim regime has never signed up to the Rome Statute, thereby avoiding the automatic scope of the International Criminal Court (ICC). However, this legal escape valve can be overcome by a UNSC recommendation.

Any prosecutions coming from the ICC are always individually targeted, and commitments to larger policies or internationally coordinated action will generally have to come from the same UNSC referral that had already been recommended, and the violation of significant United Nations/human rights ordinances. North Korea is already a signatory to the 1979 Convention on the Elimination of All Forms of Discrimination Against Women (CEDAW), the 1966 International Covenant on Civil and Political Rights (ICCPR), the 1966 International Covenant on Economic, Social and Cultural Rights (ICESCR) and importantly, the 1948 Convention on the Prevention and Punishment of the Crime of Genocide (Genocide Convention). Based on the findings of the Commission of Inquiry, North Korea was in violation of all these human rights treaties; and due to their refusal to address these violations, North Korea was facing down the spectre of humanitarian intervention.

Despite a certain amount of legal controversy casting doubt over the validity of humanitarian intervention, it has a deep and lasting historical place in the international landscape. Its origins stretch back half a century before it (Barnett 2011: 5), but humanitarianisms break-out moment came in 1859 with Jean-Henri Dunant at the Battle of Solferino. After witnessing the horrors of the battle, Dunant set in train the construction of the International Committee of the Red Cross (ICRC) and the Geneva Conventions. This was an embryonic understanding of modern conceptions of human rights, and a reciprocal claim to the need to intervene to help; essentially the statement that "if we can save innocent lives or protect populations, we should do so" (Holt \& Berkman 2006: 29).

The normativity of this moment, soon snowballed into an expanded and ever evolving legal framework for humanitarian intervention. The core of this exists in: 1 . The language of the United Nations Charter, 2. Building from the precedent established in the Paquete Habana Case (1900), which allowed for customary law to grow as a normative legal compliment (Heinze 2009: 58; Hehir 2008: 23). By interpreting the United Nations Charter in light of new human rights developments, thereby seeing it as an "organic document" (Chomsky 2012: 149), 4. As a legal restorative imperative following directly from the existing, codified, human rights documents, such as the Covenant on Civil and Political rights (1966), the Covenant on Economic, Social and Cultural rights (1966), the 
Geneva Conventions (1949 and 1977), the United Nations Charter (1945), the Universal Declaration of Human Rights (1948), the Genocide Convention (1948), and the Conventions against Torture, Cruel, Inhuman or Degrading Treatment or Punishment (1975 and 1984) (Weiss 2007: 21).

The claim to the contrary - to the illegality of humanitarian intervention as an international principle - comes from the corollary legal principle of state sovereignty, that humanitarian intervention seems to run rough shot over. Explained by Alex Bellamy, "The debate about the legitimacy of humanitarian intervention hinges on the relative value afforded to sovereignty" (Bellamy 2006a: 199). The challenge here is hard to ignore, when run through as a principle on the ground, the claim to Westphalian sovereignty is essentially a guarantee of non-intervention (Garwood-Gowers 2013: 84). In 2004, Tony Blair summarised the principle as "a country's internal affairs are for it and you don't interfere unless it threatens you" (Byers 2005: 107). Dating back to the 1648 Treaty of Westphalia that ended the Thirty Years War, sovereignty has a similarly deep legal and moral history to that of humanitarian intervention. Coming from a long history of domination, imperialism and colonisation, the weaker nations of the world found in sovereignty a protection from the strong and a guarantee of equality in international relations.

In 1999, then Algerian President, Abdelaziz Bouteflika, defended the principle of sovereignty as being "our final defence against the rules of an unjust world" (Weiss 2007: 16). With Gareth Evans explaining its importance as, "Sovereignty thus hard won, and proudly enjoyed, is sovereignty not easily relinquished or compromised" (Evans 2006: xiv). And it has a fundamental place in international law to support its moral and emotional attachment (ICISS 2001: 1.32). Article 2(1) of the United Nations Charter clearly defines the importance that the world order be underscored by the "sovereign equality of all its members" (Weiss 2007: 15). Article 2(7) details the existing international standard of non-intervention (ICISS 2001: 2.8), and Article 2(4) warns against "the threat or use of force against the territorial integrity or political independence of any state” (Thakur 2006: 246).

Similar statements exist in the Charter of the Organisation of American States (Article 15), with "no state or group of states has the right to intervene directly or indirectly, for any reason whatever, in the internal or external affairs of any other state"; in the Charter for the Organisation of African Unity (now the African Union); and as central to other regional organisations across Asia and the Middle East (Gordon 1997: 94). The International Court of Justice (ICJ) ruled in 1949 that "between independent states, respect for territorial sovereignty is an essential foundation of international relations", and then in 1986 reasserted "the fundamental principle of state sovereignty on which the whole of international law rests" (Weiss 2007: 15). And importantly the Montevideo Convention on the Rights and Duties of States in 1933, draws a specific legal category around the entitlement to sovereignty as existing for any state that has " $a$ permanent population, a defined territory, a functioning government, and the ability to enter into relations with other states" (Weiss 2007: 14).

The disjunction between these two vital principles of the international order - the rights of the state being protected by sovereignty vs. the rights of individuals being 
protected by humanitarian intervention - was seen as the reason for the mass failure of the international community to intervene to safeguard citizens abroad during the 1990s and early 2000s. This was "a time of heightened expectations for effective collective action following the end of the Cold War" (ICISS 2001: 1), and also a time in which noncombatants increasingly became the central victims and deliberate targets of large scale conflicts (Holt \& Berkman 2006: 16). Yet, despite the need, and the existing legal apparatus, this period of heightened need showed that "the international community's actual record of preventing and halting the mass killing of civilians" according to Alex Bellamy, was "staggeringly poor" (Bellamy 2011: 1). The incongruent and highly selective use of humanitarian intervention during this period was an indication, for many people, that uncertainty produced by the legal division between sovereignty and humanitarian intervention was causing havoc (Thakur 2006: 246), and that without a legal clarification, mass atrocities and severe human rights abuses would continue to go unchecked. Along with countless other states and violators of international law, North Korea conveniently found itself protected by this legal void, and allowed to continue, largely free of cost by the international community, in its systematic human rights abuses. The Doctrine of the Responsibility to Protect (R2P) was drawn up as a solution to this.

\section{THE RESPONSIBILITY TO PROTECT (R2P)}

The Doctrine of the Responsibility to Protect (R2P) was first conceived in 2001, by a made-for-purpose panel and the International Commission on Intervention and State Sovereignty (ICISS). The ICISS report narrowed in on the problem of sovereignty by virtue of its clash with the principle of humanitarian intervention. R2P redefined state sovereignty into a new scope that limited the meaning of the term beyond what it had been before - after R2P, sovereignty was to be understood only as 'functional sovereignty'. This new imprint on the old principle circled around three pillars: 1 . Rather than being absolute, the sovereignty of any given state is dependent upon whether or not it protects the basic human rights of its population, 2. The international community is required to step in and assist any state that is actively failing in this regard, 3. Wherever the basic human rights of a state are not being met in regard to the presence of ethnic cleansing, genocide, grave or systemic war crimes, and crimes against humanity (the Four Crimes), and where international assistance is not being accepted, the international community is 'obligated' to undertake humanitarian intervention in order to resolve the issues in question (Bellamy 2010: 143).

The scope of international obligations as defined by R2P is systematised by the Responsibility to Prevent (R2Prevent), the Responsibility to React (R2React) and the Responsibility to Rebuild (R2Rebuild) - effectively demanding that all stages of conflict prevention/resolution are covered by the doctrine. And the threshold for when any given country ought to have R2P ramifications enforced upon is defined by the categories of 'right intention', 'last resort', 'proportionality', 'reasonable prospects' 'right authority' and 'just cause'; in the best traditions of 'Just War Theory' (ICISS 2001). The hope was that it would radically alter the way states related to their citizens, and the way citizens understood the responsibilities of their governments. In this, three fundamental changes were envisioned: 1 . The lives and wellbeing of citizens were to be intimately linked to their state, 2. Beyond having a responsibility to their own populations, states have an equally important responsibility to the international community and global citizens, 3 . A 
new commitment to long-term justice is outlined, whereby the behaviours and/or failures of all states will be held to account by the international community (ICISS 2001: 2.15).

As much as anything, R2P was a response to the human rights catastrophes that occurred in the 1990s and early 2000s, and the "dismay" at the failure of the international community to address these situations through humanitarian intervention (GarwoodGowers 2013: 82) (Evans 2012). The new doctrine would stand as a means of "reconciling the principle of shared responsibility with that of non-intervention" (ICISS 2001: 8.3); it would become a means to "bridge the sovereignty versus intervention divide" (Evans 2006: 712). Prior to R2P, all signatories to the United Nations Charter and further significant international treaties, had explicitly accepted certain limitations on their sovereign control. What R2P did was to change this failed standard by imposing a broader international obligation upon all member states to view third party human rights violations as something for which they have a remedial responsibility. This new standard surrounded itself with a strong legal foundation, as existed in the Draft Articles on the Responsibility of States for Internationally Wrongful Acts, in Common Article 1 of the Geneva Conventions, the International Law Commission, the United Nations independent inquiry into the genocide in Rwanda, and the International Court of Justice's (ICJ) report into the 'Bosnia-Serbia' conflict (Bellamy 2010: 161).

The concept of R2P quickly shifted into legal solidity (Hehir 2012: 19) and normativity (Weiss 2007: 1) in 2005 after its adoption at the United Nations World Summit. Within six months, the doctrine was reaffirmed, then again in 2009 during the United Nations General Assembly (UNGA) debate on "implementing the Responsibility to Protect", and subsequently also in 2011. Increasingly seen as an "obligatory reference point in academic discourse on the issue of humanitarian intervention" (Hehir 2012: 4), R2P has been referenced in the United Nations' statements on the protection of children in conflict zones, global efforts to restrict light armaments, and the general rights of citizens to avoid armed conflict. In Presidential statements by the United Nations Security Council (UNSC), R2P became a barometer for declarations and commitments concerning international peace and security, the protection of civilians, the future of peace in Africa, stability in Central Africa, and the rights of children in the Middle-East; as well as UNSC resolutions specifically targeting Mali, Yemen, Sudan, Central African Republic, Burundi, Democratic Republic of Congo, Libya, and Cote d'Ivoire; all the while offering a significant new impetus in the creation of institutional architecture, such as the Peacebuilding Commission (Bellamy 2011: 110) (Evans 2006: 714).

In practical terms, the real time application of R2P was "widely credited with having helped... stave off the escalation of violence in Kenya" (Bellamy, 2010, p. 153). The onset of violence in 2007 following the Kenyan presidential election resulted in the quick-fire deaths of 1000 people and the internal displacement of 250,000. Via the Special Advisor on the Prevention of Genocide (OSAPG), the language of R2P was employed as a remedial measure for the ratcheting violence, and the specific behaviour of Kenyan political leaders was highlighted as the primary concern. The mere mention of the doctrine was enough to stop the inflammatory speeches and live broadcasts of incitement to violence. Significant human suffering was avoided simply by the shadow being cast by the international community's new tool (R2P) against human rights violations (Hehir 2012: 131), (Bellamy, 2010, p. 154). (A similar pre-emptive halt to 
violence by the mere use of R2P language was also achieved in Sri Lanka (Bellamy, 2011, p. 88).

It was really in Libya that R2P found itself through practical application. It was deployed almost immediately as rhetoric in response to Muammar Gaddafi's initial violent suppression in early 2011. This was followed up with a series of asset seizures, embargoes and travel restrictions on February 26, as well as an important referral to the International Criminal Court (ICC). Resolution 1973 soon followed on March 17 authorizing international military intervention in Libya under the guise of R2P related violations. Specifically, Gaddafi and his regime were targeted, with his own citizens seen as in need of immediate protection. Responding to a national uprising championing amongst other things - democratic reform, Gaddafi explicitly violated his R2P obligations by announcing to his population "We are coming tonight... we will find you in your closets... we will show no mercy" (Hehir, 2012, p. 13). By October, the regime was toppled, and Gaddafi was dead; and importantly R2P had a solid normative footing in the world. The hope was that it would become the standard from where the international community could finally "say no more Holocausts, Cambodias, and Rwandas" (Weiss, 2011, p. 5) (Garwood-Gowers, 2013, pp. 87-88).

The hype and the expectations were real. R2P was suddenly ringing in the ears of repressive regimes around the world, and all governments were either unwilling or unable to correct severe human rights violations. And those in a position to help deploy the doctrine in practice were championing it as the great single solution which, by its absence for so long, the global landscape was pock-marked by mass atrocities. Kofi Annan declared "I believe we must embrace the responsibility to protect, and, when necessary, we must act on it" (Evans, 2006, p. 714); then British Foreign Minister, Jack Straw, hailed the doctrine by stating, "if this new responsibility had been in place a decade ago, thousands in Srebrenica and Rwanda would have been saved" (Hehir, 2012, p. 127); and Gareth Evans, Chairman of the original R2P report, pronounced "Maybe, just maybe, we'll be able to say 'never again' in the future without having to periodically look back, as has so often been the case in the past, asking ourselves, with a mixture of anger, incomprehension and shame, how did it happen again" (Stark, 2011). A new era of human rights accountability was suddenly upon the global community, and North Korea, by any reasonable consideration, would likely be in its sights, if not the principle target.

\section{THE RESPONSIBILITY TO PROTECT AND NORTH KOREA}

With R2P firmly in place and operational - though still embryonic - the regime in North Korea ought to have been increasingly concerned about what this would mean for them. Certainly, the applicability of R2P to the North Korean case study was earnestly being discussed in some academic circles. The international community had, by virtue of the new doctrine, a responsibility to the population of North Korea; a responsibility that had, at its sharp point, a legally binding obligation for all member states to intervene in North Korea if they failed to uphold basic human rights principles. The work of Alex Bellamy helps to layout the scope of this case against North Korea through a five-point analysis of the doctrine and its applicability (Bellamy, 2015). 
Firstly, R2P is "universal and enduring in its coverage", meaning it applies in all places and at all times. In a way, the question of whether or not R2P has a role to play in any given country is essentially a failure to understand the doctrine itself. R2P always applies, because states always have an obligation to protect their populations. Through its defined scope, there are some limitations - specifically, it must be related to the Four Crimes (war crimes, ethnic cleansing, crimes against humanity and genocide). In this, North Korea falls easily within the scope of R2P, as shown by the United Nations Commission of Inquiry.

Secondly, Bellamy highlights the deliberate language of the 2005 World Summit where in adopting R2P, they used the descriptor 'populations' rather than 'citizens'. The choice was to fence off any future problems of a state delineating between people within their territory who are citizens and those who are not, and then choosing not to adequately protect the latter category. This not only limits North Korea's ability to deny certain rights to sections of its population based on bad 'Songbun' - or North Korea's centrally imposed caste system - but also has an impact on neighbouring countries, such as China. These countries have an obligation to protect North Korean migrants and asylum seekers as they do their own citizens; especially when it has been shown that returning such people would also likely mean exposing them to crimes against humanity, and that individual returnees are punished for their failed escapes.

Thirdly, R2P, as explained earlier, is "based on well-established principles of international law", and the Four Crimes in which it addresses are uncontrovertibly aspects of existing law. The duty that states have to halt and prevent the Four Crimes was not new, only the scope and nature of that duty are, and R2P via the World Summit made clear the means by which the new doctrine should be applied - that is through the mechanisms of the United Nations Charter. In this regard, North Korea is already a signatory to many of the important international treaties that R2P applies; so, it is not for North Korea to choose whether or not R2P applies to them, they have already, by default, signed-up to it.

Fourthly, Bellamy talks on the importance of 'prevention' under R2P auspices when it comes to the Four Crimes. All other R2P measures should only ever be considered after prevention is no longer an option, or when this is likely to be so (Article 42 of the United Nations Charter). North Korea has no defence in this regard, by the claim that it is not, or that it cannot be shown that they are, actively committing any of the Four Crimes. The very strength of R2P comes from the fact that specific acts need not to be actually present in order for the international community to act; only that there is a real danger that they might happen soon, or into the future. So, the obstinance of the North Korean regime in denying any real human rights reporting within their borders is not a protection against the scope of $\mathrm{R} 2 \mathrm{P}$.

Lastly, R2P is much more than a legal principle for humanitarian intervention. It is a much more comprehensive doctrine for the protection of peoples and their accompanying human rights. So, for North Korea to see the doctrine as something inherently hostile, is a mistake in its reading. Its language is clear - it is there to 'help' states to fix their human rights deficits, and failing that, any intervention would only ever come after a long series of escalating measures, such as targeted sanctions. R2P is not a 
vehicle for regime change. As a final note on this, Bellamy shows that North Korea has participated in the United Nations reviews into their human rights situations (2011; 2013), and has permitted, even acceded to, certain elements of the United Nations special rapporteur inquiry into their country and the condition of the population. At times, the North Korean regime has shown a desire to engage with the international community over their R2P obligations, have participated in three R2P dialogues run by the United Nations General Assembly, and have - unlike other states such as Cuba and Venezuela not refused R2P in principle (Bellamy, 2015).

There are avenues into North Korea here for R2P, and any claims doubting the applicability of the doctrine, in principle, are based on fundamental misconceptions which turns us back toward North Korea's actual human rights record, and the regimes' response to the adverse findings - essentially all on which R2P's intervention trigger is hinged. The Commission of Inquiry Report in 2014 laid down a rare insight into the human rights standards of the closeted country, and a rare insight in general in the form of a single, exhaustive, authoritative, process and report; and one that evoked R2P as a remedy. Since the report, and since egregious abuses were charged against North Korea, the regime has continued to be uncooperative; having consistently denied, or only provided limited access to, the United Nations teams and NGOs. In late 2017 and early 2018, a series of new, tough international sanctions were applied to North Korea, albeit in response to nuclear and ballistic missile tests, and not their human rights failings. In 2013, North Korea's human rights concerns and the R2P's application over these matters were voiced within the report of the Special Rapporteur to the Human Rights Council. Importantly, this report looked back on the previous eight years of the United Nations' action towards North Korea, recognised that such hopeful, diplomatic approaches were not working, and unlikely to work into the future, and so a "qualitatively different approach" was needed. From this, the Commission of Inquiry was formed, not as a placeholder for inaction, but as a platform towards stronger, harder-edged R2P action.

The Special Rapporteur drew attention to the importance of fact finding missions, and that any attempt to limit access ought to be seen as North Korea refusing to address its own human rights deficits; that if the international community allowed limited access to be a barrier to the application of R2P, then R2P would never be able to properly function, and its final two pillars, related to the international community, would be meaningless. The nine categories that the Commission of Inquiry charged North Korea with violating systemically, have already been laboured over, but, more importantly, through the charge of crimes against humanity, they opened them up to prosecution via Article 7 of the Rome Statute. Essentially, six categories of victims were outlined by the Commission of Inquiry - political prisoners, regular inmates at prison camps, religious groups, defectors, the population in poverty, and foreign abductees - of which the international community would need immediate access in order to avoid the need for humanitarian intervention. In five out of the six categories, crimes against humanity were designated to be "intrinsic to the fabric of the state" and "on-going". And from this report, the Commission of Inquiry also made the important pre-echo of mentioning that a lack of information and access had stopped the inquiry from finding sufficient evidence of genocide (Willis, 2014). 
At an 'Arria-formula meeting' following the Commission of Inquiry Report, accessible to all the United Nations members, saw the United Nations Security Council members seek to have North Korea brought into their formal agenda, and with increased scrutiny by the Special Rapporteur and the High Commissioner. Six Security Council members wanted to escalate the matter through an International Criminal Court referral, while others sought the same avenue of punishment through other means of international criminal justice. Following this, and in the aftermath of the Commission of Inquiry, the Security Council proposed the formation of the 'human rights contact group'; once again staring down the increasing obstinance of the North Korean regime, and the recognition that an R2P mandate for forced intervention was looking like the only way to address the problem. Constructive ways to resolve the crisis were running out, and at a sitting of the United Nations General Assembly, the North Korean human rights issue was constructed as a ministerial-level 'side event'. The intention was to seek a way of addressing the findings of the Commission of Inquiry, and eliciting change in North Korea through the demonstration of broad, global pressure. Within a month, North Korean representatives came before the General Assembly and put a final nail in hopes of a peaceful solution by submitting an alternative resolution, without any real application and dismissive of the Commission of Inquiry Report (Willis, 2014).

With the Inquiry report on one hand and R2P on the other, the issue of resolving North Korean human rights violations never had such momentum behind it, nor as much international attention. The impetus was back on the United Nations Security Council to act on their signed, and committed to, obligation to intervene in North Korea and impose a remedy that the Pyongyang regime were refusing to undertake themselves. The first pillar of R2P had been passed, the country was proven to have 'manifestly failed' to have protected its own population. The only thing left to do was enact the requisite parts of the United Nations Charter, and undertake the 'timely and decisive action' that R2P demanded of all member states.

\section{NORTH KOREA'S AVOIDANCE FRAMEWORK}

The R2P-led intervention in Libya seemed to set an international standard, a marker upon the global order stating that mass atrocities, or threats to them, would result in swift international military action. And the euphoria at the time was certainly genuine. Muammar Gaddafi's threat to "cleanse Libya house by house" had demonstrated to the international community that he was unlikely to be talked down, and that anything short of military force would fall short of stopping him. By this standard, North Korea was also a prime candidate for a R2P military intervention, whereby all conceivable measures short of this had failed. Yet the opposite reality was forming - as the world championed the new doctrine and spoke of a bright new future for human rights, North Korea remained "almost entirely overlooked" (Bellamy, 2011, pp. 67-68). While R2P was building momentum, and literature on its applicability was building, its engagement with North Korea was obvious only by its absence of attention. Academic journals dedicated to R2P went years without publishing a single article on North Korea, and while books on Libya and Syria were a dime-a-dozen, the regime in Pyongyang were spared the same level of concern. When it came to the North Korean case study, the academic community, national governments, NGO's, and supranational organisations such as the United Nations were oddly willing to avoid the issue altogether (Willis, 2014). The regime in 
Pyongyang, in spite of their obvious R2P failings, had found a way to not only avoid the scope of serious military action, but to largely avoid the touch of R2P altogether.

The first element in this avoidance framework is China. A lot of lazy reporting on the 'friendship' between North Korea and China, dating back to Mao Zedong's gesture of comparing the two countries as being as "close as lips and teeth", has clouded the true nature of the relationship. There has always been an uneasy dislike between the two. During the Korean War, Kim Il-sung denied China access to their railways despite both fighting on the same side, and despite China's entry into the war largely saving North Korea from defeat. In the same conflict, Chinese soldiers were forced to turn their weapons on their North Korean allies in order to get them to stop executing captured troops. And the distrust escalated further when China, along with the Soviet Union, deliberately delayed the signing of the armistice in order to further exhaust America's war fighting capabilities (to the complete dismay of an increasingly desperate Kim Ilsung). The relationship began as distrust and dislike, and never really improved. But from the outside, what is often seen is a Chinese state protecting its North Korean neighbour at every opportunity. The calculations for this are no great revelation - wanting stability on their border, and wanting to avoid having an American-allied South Korean state annex the North and move upwards to the Chinese doorstep.

Humanitarian intervention in North Korea, or even the sort of human rights reforms that have been talked about, would have the likely outcome of regime collapse. Such a collapse would precipitate massive refugee flows across the Yalu and Tumen rivers into China. Considering the large ethnic Korean populations already in North-East China, the total number of people that would be tempted out of North Korea could be in the millions. Under such a collapse scenario, China would also have to contend with the problem of loose nuclear and biological weapons either exploding near their territory or, more likely, being smuggled in for sale on the black market. If in the unlikely case of a smooth regime transition, North Korea would very likely soon be incorporated back into a unified Korean state, under a South Korean absorption. This would potentially bring American military hardware (through South Korea's defensive alliance with the United States) up to the Chinese border. The presence of such hardware presently in South Korea - such as the THAAD missile defence system - already has the Chinese government concerned that it may be used to target them in the future, thus, the potential of moving such instalments closer to the border rightly has China even more worried. And all of these unpleasant hypotheticals of the Chinese government do not mention the problems that will filter into China from what would certainly be a messy and protracted international conflict on their border. So, China, increasingly frustrated by North Korea's international provocations, have consistently found it to be in their interests to support the regime in Pyongyang - protecting them from international sanctions by allowing crossborder trade, and from international intervention through vetoes in the United Nations Security Council - simply because the alternative holds greater risks.

The second aspect in North Korea's avoidance framework is the presence of a credible international military threat. The spectre of nuclear weapons hung heavy over the Korean Peninsula and in the mind of Kim Il-sung ever since the Korean War - when General MacArthur heavily petitioned Washington to allow him to use the nuclear arsenal; and when Kim Il-sung witnessed first-hand the reluctance of the Soviet Union to 
directly engage with America for fear of escalation into a nuclear conflict. With lessons learnt, by the 1970s North Korea had an embryonic nuclear program up and running with original help from the Soviet Union. Since this time, attempts to get the regime to dismantle the program have come and gone with the 1994 Agreed Framework, the Six Party Talks of the early 2000s, and through six separate nuclear tests. The original reasons for the program may have had a defensive element, but, with a substantial defensive deterrent already in place in the form a 10,000's artillery placements targeting Seoul, the program is now surviving on the back of Songun - or Military First Policy, a concocted ideology, by which the regime could survive the famine years of the late 1990s and the realisation that North Korea's standard of living had fallen behind its Southern compatriots, by claiming that an aggressive outside world require a military build-up; hence explaining away the daily sufferings of ordinary North Koreans. And as ideologies tend to do, it stuck, and remains an animating theme of North Korean identity and survival. Add to these increasing displays of missile technology and mass peace-time conscription, North Korea has deliberately constructed itself to pose as an international military threat.

But, as mentioned, in terms of sheer deterrence, none of this was needed beyond the artillery placements north of Seoul. What the broader military posturing has done for the regime in North Korea is distract from the human rights issues that R2P was designed to respond to; and to make the international community consider all issues short of nuclear disarmament and an end to military provocations to be lesser concerns. As North Korea tests long-range missiles, explodes new nuclear devices and sinks South Korean naval boats (ROKS Cheonan), there is often no shortage of official reprimands, international sanctions and commitments for future escalation if North Korea continues in such patterns. These concerns have understandably become a lightning rod for international attention on North Korea. But, 'pattern' is the operative word here, not only in terms of nuclear and missile testing where the development requires cycles of tests followed by cycles of analysis and construction, but also in terms of deliberate international provocation. North Korea tends to time new tests to coincide with important American holidays - a way of poking the world for attention. The response is predictable, and when the national security of a country like South Korea, Japan or even America is being questioned, it is hard to exhaust much energy on the human rights violations inside North Korea - despite being the graver concern.

The third part of North Korea's avoidance framework is one that has been getting a lot more traction around the world, with other states deploying the same strategy to silence international human rights questions, that is, making all approaches on the topic, or any attempt to raise the issue, an automatic non-starter for discussions. This is how North Korea has dealt with the international community for decades now, certainly outside of the bounds of the United Nations. Any attempt to engage North Korea directly on the issue of their human rights abuses is met invariably by silence, and inserting the issue into existing discussions over the nuclear issue for example, has become the trigger for North Korean negotiators to walk out of the talks. The strategy is simple, even juvenile, but it has worked. By making talking about broader security issues contingent upon not talking about human rights, the international community has, as you would expect, chosen to accept the imposed standard. Prior to the Commission of Inquiry and related Security Council actions, the Security Council failed year-after-year to directly 
address North Korea's rolling human rights abuses; during the same period North Korea's nuclear program was a topic of keen interest (Willis 2014). Better to have talks on resolving one set of problems only, than to have no talks at all, as the logic goes. In the well-meaning international mind this is justified by the thinking that after one problem is fixed then we can turn our gaze elsewhere; while the mind of the North Korean regime has recognised it is now in their interest to make sure the broader security issues never go away, lest they have nothing to buffer against human rights accusations.

And as a final imprint on the avoidance framework, North Korea, through chance and design, has made itself a very difficult country to conduct a military campaign against. This is not a question of their war fighting capabilities, but, a deep challenge of avoiding a long, protracted, messy and expensive engagement. The regime had spent considerable resources building an underground city (of sorts) beneath Pyongyang, where government operations can continue, and where the regime elites will be safe from targeted bombing. Surrounding this is a heavily militarised society where every adult male is required to finish ten years of military service, and where there has been a steady, generational push toward fortification and contingency planning. The broad geography of Korea presents a further challenge, with a landscape dominated, and partitioned, by mountains. This makes a quick offensive difficult, offers ample opportunities for ambush, and limits the flow of information (all problems that historically limited forces back during the three kingdoms era and during the Korean War).

Lastly, North Korea is a country that has practiced a unique form of information isolation and ideological indoctrination. Meaning, the challenge of getting ordinary North Koreans to support an intervention, and embrace the foreign invaders is immense. North Korea - by design and by chance - has stumbled upon a highly successful framework for avoiding the auspices of R2P and its related legal doctrines/remedies. A human rights violator's field guide thus, can be read briefly as:

1. Have a powerful neighbour against whom you can leverage your weaknesses;

2. Create a viable threat to international peace and security;

3. Show a false willingness to dismantle this threat, just so long as your human rights obligations are not mentioned; and

4. Make any intervention appear as difficult, messy and costly as possible.

\section{CONCLUSION AND THE FUTURE OF R2P}

The doctrine of the Responsibility to Protect (R2P) was designed to bridge the divide between best humanitarian practice and the sovereign protection of states. Its applicability to the grave human rights abuses in North Korea, as expounded in the Commission of Inquiry Report, was immediately obvious. By the letter of the doctrine, North Korea should have been subject to an R2P-led intervention in order to halt systemic human rights abuses that the regime in Pyongyang proved unwilling to address themselves. Yet, through a series of factors, the North Korean state has managed to construct an avoidance framework for R2P related interventions, which opens up a new question mark over $\mathrm{R} 2 \mathrm{P}$ as a doctrine and its continuing place in the international community. If nations can freely commit systemic and ongoing human rights abuses and still fall outside its real-time scope, then what does this say about R2P itself? There is a 
significant aspect of the doctrine that its framers to a degree overlooked, and that the global euphoria clouded. That is, as important as the sovereignty vs. humanitarianism divide might have looked from the outside, what was really holding the principle of humanitarian intervention back prior to R2P and causing such schizophrenic application, was the same thing that has crippled R2P since its induction - namely a pervasive lack of political will to action.

North Korea is an outlier case in just how little attention it received, but it was by no means the only substantial failure of R2P. In Libya, despite the pressing need, Resolution 1973 skirted away from the doctrine through ambiguous wording of "reiterating the responsibility of the Libyan authorities to protect the Libyan population" (Hehir 2012: 13). When it came to Syria, the international community was constantly deadlocked over the issue of intervention, and only issued Resolution 2188 by the auspices of the Chemical Weapons Convention (Garwood-Gowers 2013: 82, 94). The failure of the doctrine to address the crisis in Darfur was so pronounced that it caused Lee Feinstein to claim, "If Darfur is the first 'test case' of the responsibility to protect, there is no point in denying that the world has failed the entry exam" (Feinstein 2006: 38). Conflict zones from Sri Lanka, to Kenya, Mali, Somalia, and the Democratic Republic of Congo were all continuing along either unchecked, or only partially so, by R2P.

In this, the barrier of political will was always be present and unavoidable. Regardless of the specific case on hand, R2P interventions would always be "limited to situations in which states had the political will to bear substantial financial and human costs" (Weiss 2007: 51). Following the World Summit Outcome, Aidan Hehir noted that "political will is the variable upon which the entire utility of $R 2 P$ is now predicated" (Hehir 2012: 53). At the 2009 General Assembly Debate on R2P, the Swiss representative highlighted the need for "political will at the right time", the Canadian contingent talked about the vital need of "the goodwill of states", and the Americans called for all member states to "work to summon the courage of our convictions - and the will to act" (Hehir 2012: 127). Gareth Evans, as Co-Chair of the ICISS report, made a note that "without the exercise of political will by the relevant policy makers at the relevant time, almost none of the things for which this book has argued will actually happen" (Evans 2008: 119). Again, Gareth Evans, this time writing with his Co-Chair Mohammed Sahnoun made the ominous reach into the future, stating that if $\mathrm{R} 2 \mathrm{P}$ continued to fail in this regard, then "it is only a matter of time before reports emerge again from somewhere of massacres, mass starvation, rape, and ethnic cleansing" (Evans \& Sahnoun 2002: 100).

\section{REFERENCES}

Barnett, M. (2011). Empire of humanity: A history of humanitarian intervention. New York: Cornell University Press.

Bellamy, A. J. (2006), Whither the Responsibility to Protect? Humanitarian intervention and the 2005 world summit. Ethics and International Affairs, 20, 2, 143-169.

Bellamy A.J. (2006a). Just wars: From Cicero to Iraq. Cambridge: Polity Press.

Bellamy, A. J. (2010), The responsibility to protect - Five years on. Ethics \& International Affairs, 24, 2, 143-169. 
Bellamy, A. J. (2011). Global politics and the responsibility to protect: From words to deeds. New York: Routledge.

Bellamy, A. J. (2015), A chronic protection problem: The DPRK and the responsibility to protect. International Affairs, 91, 2, 225-244.

Byers, M. (2005). War law: Understanding international law and armed conflict. New York: Grove Press.

Chomsky, N. (2012). A New Generation Draws the Line: Humanitarian Intervention and the 'Responsibility to Protect' Today. Boulder: Paradigm Publishers.

Cohen, R. (2013). "World food day: The challenge of North Korea". Brookings East Asia Commentary. Retrieved from https://www.brookings.edu/opinions/world-food-daythe-challenge-of-north-

korea/\#: :text=World\%20Food\%20Day's\%20theme\%20this,but\%20over\%20the\% 20longer\%20term.

Evans, G. (2006), From humanitarian intervention to the responsibility to protect. Wisconsin International Law Journal, 24, 3, 703-722.

Evans, G. (2012). Forward. In H. Breakey, A. Francis, V. Popovski, C. Sampford, M. G. Smith, \& M. G. Thakur (Eds.), Enhancing protection capacity: A policy guide to the responsibility to protect and the protection of civilians in armed conflicts. Queensland: Institute for Ethics, Governance and Law.

Evans, G. \& Sahnoun, M. (2002), The responsibility to protect. Foreign Affairs, 81, 6, 99-110.

Feinstein, L. "Beyond words: Building will and capacity to prevent more Darfur" (2007, January 26), Washington Post. Retrieved from https://www.almendron.com/tribuna/beyond-words-building-will-and-capacity-toprevent-more-darfurs/

Garwood-Gowers, A. (2013). The BRICS and the responsibility to protect in Libya and Syria. In R. Maguire, B. Lewis, \& V. Sampfort (Eds.), Shifting global powers and international law: Challenges and opportunities. London: Routledge.

Gordon, G. (1997). Ethics and international relations. Oxford: Blackwell Publishers.

Hehir, A. (2008). Humanitarian intervention after Kosovo: Iraq, Darfur and the record of global civil society. London: Palgrave Macmillan.

Hehir, A. (2012). The responsibility to protect: Rhetoric, reality and the future of humanitarian intervention. Shanghai: Palgrave Macmillan.

Heinze, E.A. (2009). Waging humanitarian war: The ethics, law and politics of humanitarian intervention. New York: Suny Press.

Holt, V. K. \& Berkman, T. C. (2006). The impossible mandate? Military preparedness, the responsibility to protect and modern peace operations. Washington D.C.: The Henry L. Stimson Centre.

ICISS (Report of the International Commission on Intervention and State Sovereignty) (2001). The responsibility to protect. Ottawa: International Development Research Centre.

"Report of the Commission of Inquiry on Human Rights in the Democratic People's Republic of Korea. United Nations A/HRC/25/63" (2014, February 7), United Nations Human Rights Council. Retrieved from https://www.ohchr.org/EN/HRBodies/HRC/CoIDPRK/Pages/CommissionInquiryo nHRinDPRK.aspx 
Stark, A. "Introduction in the responsibility to protect: Challenges \& opportunities in light of the Libyan intervention" (2011, November), E-International Relations. Retrieved from - http://www.e-ir.info/wp-content/uploads/R2P.pdf

Thakur, R. (2006). The united nations, peace and security: From collective security to the responsibility to protect. Cambridge: Cambridge University Press.

"U.S. blacklists North Korean officials over rights abuses" (2017, January 12), Reuters. Retrieved from https://www.reuters.com/article/us-usa-northkorea-sanctions/u-sblacklists-north-korean-officials-over-rights-abuses-idUSKBN14V2HS

Weiss, T. G. (2007). Humanitarian intervention: Ideas in action. Cambridge: Polity Press.

Willis, B. "North Korea and the responsibility to protect: Rethinking our approach to media reporting, human rights, and engagement with North Korea - Presentation for the European alliance for human rights in North Korea (EAHRNK) London Forum" (17 October 2014), London Korean Links. Retrieved from: https://londonkoreanlinks.net/2014/09/24/forum-on-north-korean-human-rightsand-engagement/ 